\title{
Vitamin D in Health and Disease - An Update
}

\author{
Nishanthi Anandabaskar ${ }^{1}$, Sandhiya Selvarajan ${ }^{2}$, Sadishkumar Kamalanathan ${ }^{3 *}$ \\ 'Department of Pharmacology, Sri Manakula Vinayagar Medical College and Hospital, Puducherry, INDIA. \\ ${ }^{2}$ Department of Clinical Pharmacology, JIPMER, Puducherry, INDIA. \\ ${ }^{3}$ Department of Endocrinology, JPMER, Puducherry, INDIA.
}

\begin{abstract}
The importance of vitamin $D$ in health and disease is being increasingly recognized nowadays and lots of research is being carried out in this area. Thus, it is essential to understand about this vitamin and this narrative review is one such initiative. The main aim of this review is to provide a comprehensive and in-depth knowledge of the role of vitamin $D$ in health and disease. A comprehensive literature search was carried out in the search portals of PubMed, Google Scholar and Indmed to identify the role of vitamin D in health and disease. Vitamin D is a fat soluble prohormone, synthesized in our epidermal cells following exposure to sunlight. The synthesized precursors of vitamin $D$ are metabolically activated by 25 -hydroxylation in the liver and $1-\alpha$ hydroxylation in the kidney. The biologically active form of vitamin $D$ is 1, 25-dihydroxycholecalciferol which binds to the vitamin $D$ receptor to mediate its effects. Vitamin D plays a key role in maintaining calcium and phosphate homeostasis in the body. However, vitamin D is also found to have various pleiotropic effects like anti-inflammatory, anti-apoptotic, anti-
\end{abstract}

fibrotic and immunomodulatory effects. The serum 25-hydroxyvitamin D levels are considered as indicator of body's vitamin D stores. Deficiency of vitamin $D$ is highly prevalent and is associated with various diseases like osteoporosis, hip fractures, myocardial infarction and malignancies of colon, breast and prostate.

Key words: Deficiency, Metabolism, Physiological role, Pleiotropic effects, Toxicity, Vitamin D.

Correspondence

Dr. Sadishkumar Kamalanathan, Additional Professor, Department of Endocrinology, JIPMER, Puducherry-605006, INDIA.

Phone: +919629528518

Email: sadishkk@gmail.com

DOI: 10.5530/jyp.2018.10.85

\section{INTRODUCTION}

A comprehensive literature search was carried out in the search portals of PubMed, Google Scholar and Indmed without any time limitation, using the search terms "vitamin D in health" and "vitamin D in disease" in order to identify the role of vitamin D in health and disease. This is an indepth review of vitamin $\mathrm{D}$ which covers various topics like discovery, biosynthesis, metabolism, dietary sources, pharmacokinetics, mechanism of action, physiological role, pleiotropic actions and recommended dietary allowances of vitamin D. It also describes about the assessment of vitamin D status, sample processing for vitamin $\mathrm{D}$ analysis, classification of vitamin D status based on serum 25-hydroxyvitamin D levels, vitamin D toxicity and vitamin $\mathrm{D}$ deficiency.

Vitamin D is a fat soluble prohormone synthesized in our body. It is also derived from plant sources, fortified foods and dietary supplements. It is metabolically activated in the liver and kidney to form 1,25-dihydroxycholecalciferol, which has various physiological roles in the body, especially in maintaining the bone-mineral homeostasis. It has also been found to have various pleiotropic effects like anti-inflammatory, anti-apoptotic, anti-fibrotic and immunomodulatory effects. This review describes in detail about the discovery of vitamin D, its biosynthesis, metabolism, physiological roles, pleiotropic actions, recommended dietary allowances, assessment of vitamin D levels, classification of vitamin D status, vitamin D toxicity and deficiency.

\section{DISCOVERY OF VITAMIN D}

Although rickets was prevalent from time immemorial, there was lack of knowledge regarding its etiology and treatment, until the discovery of vitamin D. ${ }^{1}$ In 1890, it was observed that prevalence of rickets was more in London compared to that in the tropical zones like India and China. This observation led to the speculation that exposure to sunlight was essential for prevention of rickets. ${ }^{2}$ Similarly experiments by Mellan by et al. ${ }^{3}$ in the year 1919 , found that cod liver oil could cure rickets in dogs retained indoors without access to sunlight. The study concluded that probably vitamin A or a similar substance present in cod liver oil was responsible for the improvement in symptoms of rickets in the dogs and that rickets was produced due to deficiency of vitamin A in the diet. However, a subsequent study done by McCollum et al. ${ }^{4}$ in the year 1922, revealed that a new fat soluble vitamin (which they named as vitamin $\mathrm{D}$ ) distinct from vitamin $\mathrm{A}$, was responsible for the cure of rickets in dogs. This discovery was based on the finding that cod liver oil with vitamin A destroyed by oxidation, could not prevent the occurrence of xerophthalmia but still demonstrated the antirachitic effect in dogs. Following its discovery, various researchers like Windaus, Thiele, Schenck and Werder identified the structure and properties of vitamin $\mathrm{D}$, which is derived from both plant and animal sources. ${ }^{5}$

\section{VITAMIN D - A VITAMIN OR PROHORMONE?}

Vitamin a micronutrient, essential for the survival of an organism is not synthesized in the body but is derived from dietary sources. Although vitamin $\mathrm{D}$ was initially classified as a vitamin, accumulating evidence indicated that it can be produced in our body with the help of ultraviolet radiation from sunlight, thus violating the definition of a vitamin. Thus, vitamin $\mathrm{D}$ is now thought to be a prohormone which on subsequent activation in the body gets converted to its active form 1,25-dihydroxy vitamin $\mathrm{D}$ which functions like a hormone (produced in one part of 
body, transported through blood circulation to reach a distant site where it exerts its action) and mediates the endocrine effects of vitamin D. ${ }^{6}$

\section{VITAMIN D BIOSYNTHESIS, METABOLISM, AND INACTIVATION}

Vitamin D is a fat-soluble secosteroid synthesized primarily under our skin with the help of ultraviolet radiation (Figure 1). Sunlight (UVB of wavelength 290-320 nm), acts on 7-dehydrocholesterol (provitamin $\mathrm{D}_{3}$ ) in the stratum basale and stratum spinosum layer of the epidermis and forms previtamin $\mathrm{D}_{3}$, which undergoes thermal isomerization for 3 days to form cholecalciferol or vitamin $\mathrm{D}_{3}{ }^{7}$ The rate of vitamin $\mathrm{D}_{3}$ production is influenced by the intensity of UVB radiation and melanin content of the skin. The lower intensity of UVB radiation and dark complexion limit the amount of vitamin D biosynthesis. ${ }^{7-8}$ It is estimated that on exposure of $20 \%$ of the total body surface area to ultraviolet radiation of 0.5 minimal erythemal dose (MED) produces vitamin $\mathrm{D}$ equal in amount to consumption of 1400 to $2,000 \mathrm{IU}$ of vitamin $\mathrm{D}_{3} .{ }^{9}$ Minimal erythemal dose is a measure to quantify sunlight exposure. One minimal erythemal dose is the intensity of sunlight required to impart mild pink colour in the sun-exposed areas of skin after $24 \mathrm{hr}$.

Vitamin $\mathrm{D}_{3}$ is transported in blood with the help of proteins synthesized in liver namely, vitamin D binding proteins (DBPs) to various target organs. In liver, vitamin $\mathrm{D}_{3}$ undergoes 25 -hydroxylation and gets converted to 25-hydroxycholecalciferol or calcidiol, which constitutes the primary circulating form of vitamin $\mathrm{D}$. On reaching the proximal tubular epithelial cells of the kidney, calcidiol further undergoes 1-alfa hydroxylation by the enzyme 1-alfa hydroxylase (cytochrome P27B1 or CYP27B1) to form the active metabolite 1,25- dihydroxycholecalciferol or calcitriol. ${ }^{10}$ Calcitriol mediates all the physiological functions of vitamin D. The kidneys also contain 24-hydroxylase which can hydroxylate both 25 hydroxycholecalciferol and 1,25- dihydroxycholecalciferol to their inactive metabolites 24,25- dihydroxycholecalciferol and 1,24,25- trihydroxycholecalciferol respectively. Calcitroic acid ( 1 alpha-hydroxy-23 carboxy$24,25,26,27$-tetranorvitamin $\mathrm{D}_{3}$ ) is another inactive metabolite of calcitriol produced by the action of 24-hydroxylase enzyme. These inactive metabolites are excreted through the bile into faeces. ${ }^{10-11}$

\section{DIETARY SOURCES OF VITAMIN D}

Vitamin D is also derived from dietary sources, although the major contribution of the circulating vitamin $\mathrm{D}$ pool is derived from sunlight. Dietary sources can be in the form of natural foods, fortified food products or vitamin D supplements. Very few natural foods as summarized in Table 1 are rich in vitamin D and they serve to provide the body's vitamin $\mathrm{D}$ requirement. ${ }^{12-15}$

\section{PHARMACOKINETICS OF VITAMIN D}

Various vitamin D supplements are available in the market, especially in the form of vitamin $\mathrm{D}_{2}$ (ergocalciferol) and vitamin $\mathrm{D}_{3}$ (cholecalciferol). According to a study by Lehmann et al. ${ }^{16}$ supplementation with vitamin $\mathrm{D}_{3}$ was more effective in increasing the total serum 25 -hydroxy vitamin $\mathrm{D}$ levels compared to vitamin $\mathrm{D}_{2}$ supplementation. Vitamin $\mathrm{D}$, being fat soluble is absorbed after incorporation into micelles with the help of bile salts. Its absorption occurs mainly in the proximal part of small intestine. ${ }^{11}$ It was found that absorption of vitamin $\mathrm{D}$ was increased when their supplements were taken along with a large meal, thus aiding in achieving a greater increase in serum 25 -hydroxy vitamin D levels. ${ }^{17}$ The half-life of the metabolite 25 -hydroxyvitamin D is 3 weeks, whereas that of the active metabolite 1,25 -dihydroxyvitamin D is only $4 \mathrm{hr}^{18}$

\section{MECHANISM OF ACTION OF VITAMIN D}

The active form of vitamin D or cholecalciferol namely, 1,25- dihydroxycholecalciferol or calcitriol binds to vitamin D receptors (VDR) present in the nuclei of the target cells to mediate its genomic actions. VDRs belonging to the family of nuclear receptors contain a ligand binding domain and a DNA binding domain. On binding to their cognate ligand (calcitriol), the vitamin $\mathrm{D}$ receptor heterodimerizes with retinoid $\mathrm{X}$ receptor (RXR) and this VDR-RXR heterodimer binds specifically to the vitamin $\mathrm{D}$ response elements (VDRE) of the DNA to alter the transcription of vitamin $\mathrm{D}$ responsive genes, thus mediating the genomic actions of vitamin $\mathrm{D} .^{19}$

Vitamin $\mathrm{D}$ also mediates non-genomic effects by acting on vitamin $\mathrm{D}$ receptors located on the plasma membrane of the target cells. ${ }^{6}$ They also operate by various other mechanisms like the opening of ion channels and modulation of the levels of various enzymes like kinases and phosphatases which are involved in cell signaling. Unlike, genomic actions, the transcription independent actions of vitamin D are rapid. ${ }^{20}$

\section{PHYSIOLOGICAL ROLES OF VITAMIN D}

Vitamin D plays a key role in maintaining calcium and phosphate homeostasis in the body (Figure 2). It helps to maintain serum calcium levels within its normal limits by acting on various target organs like intestine, kidneys, bones and parathyroids. It increases serum calcium levels by the following mechanisms. Vitamin D increases intestinal calcium absorption by both transcellular and paracellular pathways. This is

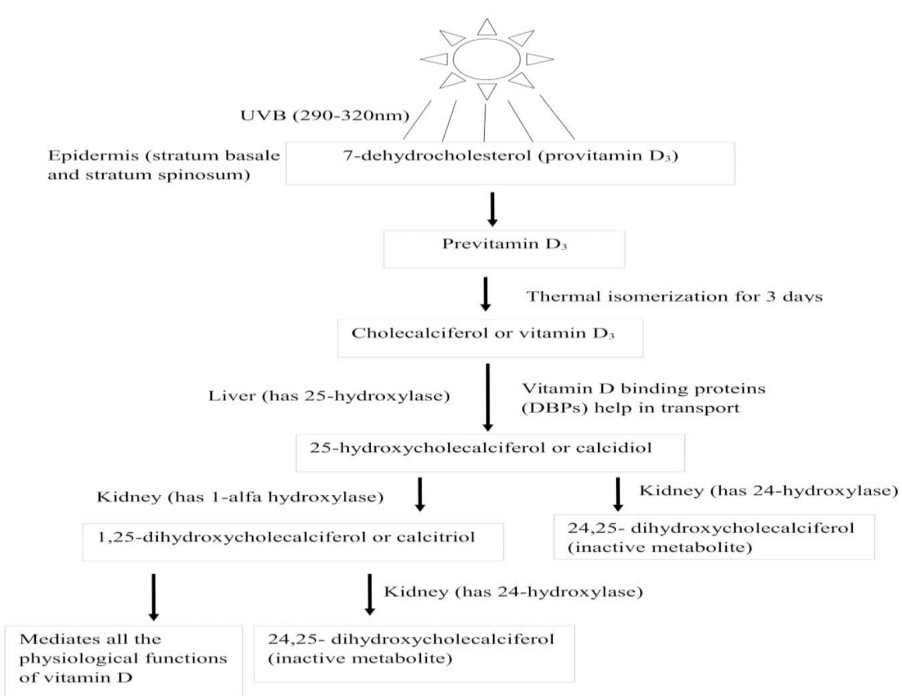

Figure 1: Synthesis and metabolism of vitamin $D .^{7-11}$ UV B rays from sun falls on epidermis, and converts 7-dehydrocholesterol (provitamin $D_{3}$ ) in the stratum basale and stratum spinosum to previtamin $D_{3}$ which undergoes thermal isomerization for 3 days to form vitamin $D_{3}$ (cholecalciferol). Vitamin $D_{3^{\prime}}$ binds to vitamin $\mathrm{D}$ binding proteins and get transported to various target organs. In liver, the enzyme 25-hydroxylase converts cholecalciferol to 25-hydroxycholecalciferol (calcidiol), which constitutes the primary circulating form of vitamin D. In the proximal tubular epithelial cells of kidney, calcidiol further undergoes 1-alfa hydroxylation by the enzyme 1-alfa hydroxylase (cytochrome P27B1 or CYP27B1) to form the active metabolite 1,25- dihydroxycholecalciferol (calcitriol). The kidneys also contain 24-hydroxylase which can hydroxylate both 25-hydroxycholecalciferol and 1,25- dihydroxycholecalciferol to their inactive metabolites 24,25- dihydroxycholecalciferol and 1,24,25- trihydroxycholecalciferol respectively. 




Figure 2: Regulation of calcium homeostasis by calcitriol and parathormone. ${ }^{21-24}$ Calcitriol and parathormone play a key role in maintaining calcium homeostasis in the body. During hypocalcemia, there is activation of calcium sensing receptors on the parathyroid glands, which leads to release of parathormone. This leads to increase in the levels of the enzyme 1-alfa hydroxylase, thus stimulating the 1-alfa hydroxylation of 25 -hydroxyvitamin $D$ to the active form calcitriol. Calcitriol increases serum calcium levels and thus restores it by acting on the intestine and kidneys. It acts on the intestine and increases intestinal calcium absorption by both transcellular and paracellular pathways. In the kidneys, it increases re-absorption of filtered calcium from distal renal tubules. Thus, both these processes lead to increase in serum calcium levels. Once normal serum calcium levels are attained, it inhibits the calcium sensing receptors on the parathyroid glands, thus reducing the parathormone levels and subsequently decreases the calcitriol levels preventing further increase in serum calcium levels. Thus, serum calcium levels are tightly regulated by calcitriol and parathormone.

accomplished by inducing the formation of various transport proteins involved in intestinal calcium absorption by the genomic actions of vitamin D. ${ }^{21}$ Vitamin D and parathormone also help in re-absorption of filtered calcium from the distal renal tubules, thus aiding in calcium homeostasis. $^{22}$

Vitamin D also plays a predominant role in the regulation of serum phosphate levels. It helps in intestinal absorption of phosphate by inducing the expression of a co-transport protein called type $2 \mathrm{~b}$ sodiumphosphate co-transporter involved in transcellular phosphate transport across intestinal epithelial cells. ${ }^{23}$

Parathormone is intricately linked to the physiological roles played by vitamin D. Membrane-bound calcium-sensing receptors are present in the parathyroid glands, which continuously monitor the serum calcium levels. When hypocalcemia sets in, these calcium-sensing receptors are activated, and they signal the parathyroid glands to release parathormone, which in turn increases the 1-alfa hydroxylase enzymatic activity. This leads to increase in conversion of 25-hydroxyvitamin D to the active form 1,25-dihydroxyvitamin D. Thus, parathormone works in synergy with 1,25-dihydroxyvitamin $\mathrm{D}$ to increase the serum calcium levels, which no longer activates the calcium sensing receptors of parathyroid. This subsequently leads to a decrease in the release of parathormone from the parathyroids. Thus, calcium homeostasis is maintained by the hormones parathormone and calcitriol. ${ }^{24}$

\section{PLEIOTROPIC ACTIONS OF VITAMIN D}

Vitamin D receptors are present at sites which are not involved in bone mineral homeostasis like the pancreas, large intestine, small intestine, muscles, and nerves. ${ }^{25}$ This discovery has provided new insights into the functions of vitamin D as a versatile signaling molecule. Thus, the role of vitamin $\mathrm{D}$ is further extended to a multitude of physiological roles beyond bone mineral homeostasis. Vitamin D is found to have antiinflammatory, anti-apoptotic, anti-fibrotic and immunomodulatory effects. ${ }^{25}$ It is also implicated in having anti-tumour action by inhibiting the growth and promoting the differentiation of cancer cells especially in colon cancer. ${ }^{20}$ It also protects against certain inflammatory diseases like inflammatory bowel disease, asthma, chronic kidney disease and nonalcoholic fatty liver disease. ${ }^{26}$ Vitamin D is involved in keratinocyte differentiation in the skin, and its deficiency is implicated in a variety of cutaneous diseases like skin cancer, psoriasis, vitiligo, pemphigus vulgaris and atopic dermatitis. ${ }^{15}$

The evidence for pleiotropic actions of vitamin D was further substantiated by the discovery of extra-renal 1-alfa hydroxylase enzymes. Their presence came to limelight when cultured pulmonary alveolar macrophages from patients with chronic granulomatous diseases like sarcoidosis exhibited 1-alfa hydroxylase activity and could convert 25 -hydroxyvitamin $\mathrm{D}_{3}$ to its active form 1,25 - dihydroxyvitamin $\mathrm{D}_{3}{ }^{27}$ Extra-renal 1-alfa hydroxylase (CYP27B1) enzymes were found in various tissues like placenta, lymph nodes, and skin. ${ }^{28}$ These enzymes aid in the local production of calcitriol which acts in an autocrine or paracrine manner on their cognate vitamin D receptors to modulate cell proliferation and differentiation. Other novel sites like adrenal medulla, brain, pancreas, and colon also demonstrated the presence of these enzymes. ${ }^{28}$ However, their precise physiological roles at extra-renal sites are yet to be demystified and warrant further studies. At present, studies have not yet been able to delineate the differences in the physiological roles played by calcitriol produced from kidney and extra renal tissues. However, studies have revealed that the extra-renal production and inactivation of calcitriol is under stringent control and is influenced by local production of various inflammatory mediators like interferon- ${ }^{29}{ }^{29}$

\section{RECOMMENDED DIETARY ALLOWANCES (RDA) OF VITAMIN D}

According to the Institute of Medicine (IOM) committee's 2011 report, adequate dietary vitamin D per day should be $400 \mathrm{IU}$ in infants, $600 \mathrm{IU}$ in the age group of 1 to 70 years, and 800 IU for individuals above 70 years of age (Table 2). This dietary recommendation is in addition to

\section{Table 1: Dietary sources of vitamin D. ${ }^{12-15}$}

\begin{tabular}{|c|c|}
\hline S. No. & Dietary source \\
\hline \multirow[t]{6}{*}{1.} & Animal sources (contain vitamin D3 or cholecalciferol) \\
\hline & Fish (salmon, mackerel, tuna and sardines) \\
\hline & Cod-liver oil \\
\hline & Beef \\
\hline & Egg yolk \\
\hline & Milk and milk products (yogurt, butter, and cheese) \\
\hline \multirow[t]{2}{*}{2.} & Plant sources (contain vitamin D2 or ergocalciferol) \\
\hline & $\begin{array}{c}\text { Mushrooms (when exposed to UVB radiation, ergosterol } \\
\text { present in them gets converted to ergocalciferol) }\end{array}$ \\
\hline \multirow[t]{4}{*}{3.} & Foods fortified with vitamin $\mathrm{D}$ \\
\hline & Milk and milk products (cheese, yogurt) \\
\hline & Orange juice \\
\hline & Bread \\
\hline \multirow[t]{3}{*}{4.} & Vitamin D supplements \\
\hline & Vitamin $\mathrm{D}_{2}$ \\
\hline & Vitamin $\mathrm{D}_{3}$ \\
\hline
\end{tabular}


minimal sunlight exposure, and it aims to achieve a 25 -hydroxyvitamin $\mathrm{D}$ concentration of $20 \mathrm{ng} / \mathrm{ml}$, which is established to be sufficient for the optimal bone health of an individual. ${ }^{30}$

As per the United States Endocrine Society Clinical Practice Guidelines, the recommended daily intake of vitamin $\mathrm{D}$ is much higher compared to the IOM recommendations. It estimated the RDA of vitamin $\mathrm{D}$ to be $1000 \mathrm{IU} /$ day in children (age group of 1 to 18 years) and 1500-2000 IU/ day in adults ( $\geq 19$ years of age). This is required to increase the serum 25 -hydroxyvitamin D levels above $30 \mathrm{ng} / \mathrm{ml}$, which is considered as appropriate vitamin D concentrations in the body to enjoy its skeletal and non-skeletal benefits. ${ }^{31}$

However, the Indian Council of Medical Research (ICMR) recommends a lower daily intake of vitamin $\mathrm{D}$ compared to the international guidelines and stresses on the need for adequate exposure to sunlight for healthy bones. According to ICMR, diet cannot substitute sunlight exposure for ensuring adequate vitamin $\mathrm{D}$ stores in the body. Thus, ICMR recommends a daily intake of $400 \mathrm{IU}(10 \mu \mathrm{g})$ of vitamin D with minimal exposure to sunlight. Unlike other guidelines, ICMR has not given any specific recommendations for vitamin D intake based on differences in age groups. ${ }^{32}$

\section{ASSESSMENT OF VITAMIN D STATUS}

In spite of the fact that 1,25-dihydroxyvitamin $\mathrm{D}$ is the biologically active metabolite of vitamin $\mathrm{D}$ biosynthesis, estimation of its serum concentration is not routinely undertaken to determine the vitamin D status of an individual. This is attributed to its short half-life of $4 \mathrm{hr}$ as serum concentrations will not reflect the vitamin D stores of the body, rather it would be influenced by the recent exposure to sunlight or dietary intake of vitamin D. Moreover, its serum concentration would be varying depending on the calcium requirements of the body. ${ }^{18}$ Therefore, measurement of serum 25-hydroxyvitamin D levels is considered as the single best indicator for estimation of the vitamin D status of a person. ${ }^{33}$ The main advantage of using 25-hydroxyvitamin D levels as a marker of vitamin D stores is that it has a longer half-life of 3 weeks, and thus its serum levels would be a better representation of body's vitamin D stores. ${ }^{34}$ Serum 25-hydroxyvitamin D levels reflect the amount of vitamin D synthesized from sunlight as well as that obtained from the dietary sources and supplements. There are two forms of 25-hydroxyvitamin D, namely 25-hydroxy vitamin $\mathrm{D}_{2}$ and 25 -hydroxy vitamin $\mathrm{D}_{3}$ obtained by 25 -hydroxylation of ergocalciferol and cholecalciferol respectively. Majority of the methods measure both the metabolites of 25-hydroxyvitamin D, namely $\mathrm{D}_{2}$ and $\mathrm{D}_{3}$ as total 25 -hydroxyvitamin $\mathrm{D}$ levels. ${ }^{35}$ The concentration of 25-hydroxyvitamin D in the blood is usually in nanomolar to micromolar range, thus requiring highly sensitive methods for its quantification.

The assay methods developed for measurement of serum or plasma 25-hydroxyvitamin D levels include high performance liquid chromatography (HPLC), radioimmunoassay (RIA), enzyme-linked immunosorbent assay (ELISA), chemiluminescent assay and liquid chromatography-tandem mass spectrometry (LCMS/MS). ${ }^{36}$

However, a lot of variation exists between the concentrations of 25hydroxyvitamin $\mathrm{D}$ estimated by the various assay platforms in different laboratories due to a lack of proper standardization procedure. ${ }^{37} \mathrm{Among}$ the various assay techniques, LCMS/MS is considered to be the gold standard method for estimating 25-hydroxyvitamin D levels to assess the vitamin D nutritional reserves of an individual. ${ }^{36}$

Apart from 25-hydroxyvitamin D levels, other biomarkers like parathormone levels, bone mineral density, and intestinal calcium absorption are also being employed to assess the vitamin D nutritional status of an individual. ${ }^{38}$ Although 25 -hydroxyvitamin $\mathrm{D}$ is the robust and reliable marker of vitamin D status, there are some cases where measurement of 1,25-dihydroxyvitamin $\mathrm{D}$ levels provide useful information. In certain conditions like chronic renal diseases (defects in 1-alfa hydroxylation), vitamin $\mathrm{D}$-dependent rickets (absence of 1-alfa hydroxylase), vitamin D resistant rickets (genetic defects in vitamin $\mathrm{D}$ receptor and associated with high circulating levels of 1,25-dihydroxyvitamin D) and granulomatous diseases like sarcoidosis (extrarenal 1-alfa hydroxylation causes increase in 1,25-dihydroxyvitamin D levels), measurement of 1,25-dihydroxyvitamin D levels is indicated..$^{33}$

\section{SAMPLE PROCESSING FOR VITAMIN D ANALYSIS}

A study was undertaken by Colak et al.,$^{39}$ to assess the influence of various parameters like sample type (serum or plasma), centrifugation temperature and storage conditions, on estimated 25-hydroxyvitamin D levels. It was found that neither sample type nor centrifugation temperature had an effect on the measured vitamin D concentration. Further, the authors observed that the stability of 25-hydroxyvitamin D was maintained over a duration of $4 \mathrm{hr}$ when placed at room temperature and for 1 day when stored at $2-8^{\circ} \mathrm{C}$. It was also noticed that preserving the samples at $-20^{\circ} \mathrm{C}$ and $-80^{\circ} \mathrm{C}$ increased the stability of the metabolite to be estimated for a period of 7 days and 3 months respectively.

In another study, done by Antoniucci et al. ${ }^{40}$ the authors noticed that the metabolite 25-hydroxyvitamin D is highly stable, and its serum concentrations are not altered by multiple freeze-thaw cycles (up to four times). The effect of delayed centrifugation of collected blood samples $(2,24,72$ and $96 \mathrm{hr}$ after blood sample collection), type of tubes for blood collection (serum tube, plasma tube with heparin as anticoagulant and plasma tube with EDTA as anticoagulant) and assay method (radioimmunoassay and chemiluminescence immunoassay) on the estimated 25-hydroxyvitamin D levels was analyzed in a study by Yu et al., ${ }^{41}$ It was observed that there was no difference in 25-hydroxyvitamin $\mathrm{D}$ levels with respect to time of centrifugation or type of assay. However, it was found that the concentration of 25-hydroxyvitamin D in heparinized plasma was higher than that in serum especially when there was a substantial delay in centrifugation.

\section{CLASSIFICATION OF VITAMIN D STATUS BASED ON SERUM 25-HYDROXYVITAMIN D LEVELS}

There is no concurrence regarding the optimal serum vitamin D levels for better health. The cut-off value for serum 25-hydroxyvitamin D levels to determine vitamin D deficiency has been a matter of debate. Various biomarkers concerning calcium metabolism have been used to define the optimal 25-hydroxyvitamin D levels to maintain healthy bones. These biomarkers are serum parathormone levels and intestinal calcium absorption. It has been demonstrated that there is an inverse correlation between serum 25-hydroxyvitamin $\mathrm{D}$ levels and serum parathormone levels. ${ }^{42}$ When serum 25 -hydroxyvitamin D levels are $<32 \mathrm{ng} / \mathrm{ml}$, there is an elevation in the serum parathormone levels (secondary hyperparathyroidism) and once 25-hydroxyvitamin D levels reach this threshold concentration $32 \mathrm{ng} / \mathrm{ml}$, serum parathormone levels normalize, and there is subsidence of secondary hyperparathyroidism. ${ }^{43}$

Similarly, it was also found that there was an increase in intestinal calcium absorption with rise inserum 25-hydroxyvitamin D levels, and it reached a peak at serum 25-hydroxyvitamin D concentrations of $32 \mathrm{ng} / \mathrm{ml}$ and plateaued thereafter. This indicates that the maximum absorptive capacity for intestinal calcium has been achieved with serum 25-hydroxyvitamin D concentrations of $32 \mathrm{ng} / \mathrm{ml}^{44}$ It was thus proposed that serum 25 hydroxyvitamin D level $<32 \mathrm{ng} / \mathrm{ml}$ to be used as the cut-off for classification of vitamin D deficiency. ${ }^{43-44}$

Later, two professional organizations (US Endocrine Society and Institute of Medicine) have given their recommendations regarding the optimal 
Anandabaskar, et al.: Vitamin D Update

\begin{tabular}{|c|c|c|c|}
\hline S.No. & Name of the Guidelines & Age group & $\begin{array}{c}\text { Recommended } \\
\text { dietary } \\
\text { allowances (RDA) } \\
\text { of vitamin D }\end{array}$ \\
\hline \multirow[t]{3}{*}{1.} & \multirow{3}{*}{$\begin{array}{l}\text { Institute of Medicine (IOM) } \\
\text { committee's } 2011 \text { report }\end{array}$} & Infants & $400 \mathrm{IU}$ \\
\hline & & 1 to 70 years & $600 \mathrm{IU}$ \\
\hline & & above 70 years & $800 \mathrm{IU}$ \\
\hline \multirow[t]{2}{*}{2.} & \multirow{2}{*}{$\begin{array}{l}\text { United States Endocrine } \\
\text { Society Clinical Practice } \\
\text { Guidelines }\end{array}$} & 1 to 18 years & $1000 \mathrm{IU}$ \\
\hline & & $\geq 19$ years of age & $1500-2000 \mathrm{IU}$ \\
\hline 3. & $\begin{array}{l}\text { Indian Council of Medical } \\
\text { Research (ICMR) }\end{array}$ & All age groups & $400 \mathrm{IU}$ \\
\hline
\end{tabular}

levels of 25-hydroxyvitamin D required for good bone health which is summarized in Table 3. ${ }^{31,45}$

Paul Lips has proposed a classification of vitamin D deficiency into mild, moderate and severe, based on serum 25-hydroxyvitamin D levels. $\mathrm{He}$ has classified serum 25-hydroxyvitamin D levels of $10-20 \mathrm{ng} / \mathrm{ml}$ as mild, $5-10 \mathrm{ng} / \mathrm{ml}$ as moderate and $<5 \mathrm{ng} / \mathrm{ml}$ as severe vitamin D deficiency. ${ }^{46}$ The conversion factors for various units used to quantify 25-hydroxy vitamin D levels are $1 \mathrm{ng} / \mathrm{ml}=2.5 \mathrm{nmol} / \mathrm{l} ; 1 \mu \mathrm{g}=40 \mathrm{IU}=2.5 \mathrm{nmol} .{ }^{45}$

\section{VITAMIN D TOXICITY}

Vitamin D toxicity refers to serum 25-hydroxyvitamin D levels $>150 \mathrm{ng} / \mathrm{ml}$. Hypercalcemia, decrease in parathormone levels and elevated urine calcium levels are other biomarkers of vitamin D toxicity. ${ }^{47}$ Vitamin D toxicity occurs due to overconsumption of vitamin $\mathrm{D}$ supplements or fortified food products. Dietary intake of vitamin D containing natural foods contributes to only 10-20\% of circulating 25-hydroxyvitamin D levels and hence does not lead to vitamin D toxicity. ${ }^{35}$

Prolonged exposure to sunlight does not lead to vitamin $\mathrm{D}$ toxicity as it is a self-regulated process. During prolonged UVB exposure, the synthesized previtamin $\mathrm{D}_{3}$ gets converted into biologically inert photo-isomers namely lumisterol and tachysterol. These isomers have a very low affinity to vitamin D binding proteins, and thus they remain at their site of synthesis in the epidermis and cannot be translocated into the blood stream. Moreover, they are lost with natural skin turnover, thus protecting the body from the risk of vitamin toxicity. ${ }^{7}$

The manifestations of vitamin D intoxication are nausea, vomiting, abdominal pain, anorexia, constipation, polydipsia, polyuria, myalgia, bone pain, osteoporosis, metastatic calcification, arrhythmia, and seizures. ${ }^{47}$ Treatment includes discontinuation of vitamin D intake, low calcium diet, intravenous fluids, diuretics, and steroids. However, the main aim of therapy revolves around management of hypercalcemia. ${ }^{47}$

\section{VITAMIN D DEFICIENCY}

Vitamin D deficiency has become a global pandemic and is highly prevalent in all age groups, including children, adolescents, adults, pregnant and lactating women. ${ }^{48}$ According to a systematic review of vitamin D status in healthy Indians, the mean 25-hydroxyvitamin D levels ranged from $3.15 \pm 1.4$ to $52.9 \pm 33.7 \mathrm{ng} / \mathrm{ml}$ and vitamin D deficiency was prevalent in all parts of India. ${ }^{49}$ According to another study by Shivane et al., ${ }^{50}$ the prevalence of vitamin D deficiency $(<20 \mathrm{ng} / \mathrm{ml})$ in young healthy Indian adults was found to be $70 \%$. Thus, despite being a country with abundant sunshine, India also faces the problem of vitamin D deficiency.

The high prevalence of hypovitaminosis can be attributed to multiple causes. Since sunlight is the major contributor to the body's vitamin D stores, the major causes of vitamin D deficiency are lack of adequate
Table 3: Classification of vitamin D status of an individual. ${ }^{31,45}$

\begin{tabular}{|c|c|c|c|}
\hline \multirow{2}{*}{ S.No. } & \multirow{2}{*}{$\begin{array}{c}\text { Classification } \\
\text { of vitamin D } \\
\text { status }\end{array}$} & \multicolumn{2}{|c|}{ Serum 25-hydroxyvitamin D level } \\
\hline & & $\begin{array}{l}\text { US endocrine } \\
\text { society }\end{array}$ & $\begin{array}{l}\text { Institute of medicine } \\
\text { (IOM) }\end{array}$ \\
\hline 1. & $\begin{array}{l}\text { Vitamin D } \\
\text { deficiency }\end{array}$ & $\begin{array}{c}<20 \mathrm{ng} / \mathrm{ml}(<50 \\
\mathrm{nmol} / \mathrm{l})\end{array}$ & $<12 \mathrm{ng} / \mathrm{ml}(<30 \mathrm{nmol} / \mathrm{l})$ \\
\hline 2. & $\begin{array}{l}\text { Vitamin D } \\
\text { insufficiency }\end{array}$ & $\begin{array}{c}21 \text { to } 29 \mathrm{ng} / \mathrm{ml}(52.5 \\
\text { to } 72.5 \mathrm{nmol} / \mathrm{l})\end{array}$ & $\begin{array}{l}12 \text { to } 20 \mathrm{ng} / \mathrm{ml}(30 \text { to } \\
50 \mathrm{nmol} / \mathrm{l})\end{array}$ \\
\hline 3. & $\begin{array}{l}\text { Normal } \\
\text { vitamin D } \\
\text { levels }\end{array}$ & $\begin{array}{c}\geq 30 \mathrm{ng} / \mathrm{ml}(\geq 75 \\
\mathrm{nmol} / \mathrm{l})\end{array}$ & $>20 \mathrm{ng} / \mathrm{ml}(>50 \mathrm{nmol} / \mathrm{l})$ \\
\hline
\end{tabular}

exposure to sunlight, use of sunscreen and increased melanin content of the skin. It could also be due to lack of intake of vitamin D-rich foods or defect in intestinal absorption of vitamin $\mathrm{D}$ (fat malabsorption disorders or use of medications like cholestyramine which interfere with intestinal fat absorption). ${ }^{51}$ Other reasons are intake of drugs affecting vitamin $\mathrm{D}$ metabolism eg. glucocorticoids, anticonvulsants, and anti-HIV drugs. ${ }^{11}$ The presence of hepatic and/or renal diseases predispose to vitamin D deficiency due lack of conversion of vitamin $\mathrm{D}$ into its biologically active form. ${ }^{11}$ Old age (reduced 7 -dehdrocholesterol content of epidermis) and obesity (sequestration of vitamin D in the adipose tissues) are also risk factors for vitamin D deficiency. ${ }^{51}$

Vitamin D deficiency has many implications as vitamin D is intricately linked with maintenance of calcium homeostasis. It is associated with defect in mineralization of the skeleton and manifests either as rickets or osteomalacia in children and adults respectively. ${ }^{52}$ Vitamin D deficiency leads to a decrease in intestinal absorption of calcium and phosphate with resultant hypocalcemia stimulating the release of parathormone, thus producing secondary hyperparathyroidism. Parathormone causes calcium mobilization from the bones to restore the serum calcium levels, thus leading to the development of osteopenia and osteoporosis. ${ }^{53} \mathrm{~A}$ prospective cohort study in elderly individuals found that patients with low vitamin $\mathrm{D}$ levels had a higher risk of developing hip fractures compared to those with adequate vitamin D status. ${ }^{54}$ Another cohort study by De Boer et al. ${ }^{55}$ has shown that low 25 -hydroxyvitamin D status $(<20 \mathrm{ng} / \mathrm{ml})$ is associated with increased risk of hip fractures, myocardial infarction, cancer and death in a population of older adults over a follow-up period of 11 years. Studies have also shown that vitamin D deficiency is also associated with increased arterial stiffness and increased risk for adverse cardiovascular outcomes and all-cause mortality. ${ }^{56-59} \mathrm{~A}$ substantial body of evidence indicates the association between vitamin $\mathrm{D}$ deficiency and various malignancies like colon, breast and prostate cancers. ${ }^{60}$ Vitamin D deficiency is also associated with other diseases like inflammatory bowel disease, asthma, vitiligo, pemphigus vulgaris and atopic dermatitis. ${ }^{15,26}$

Vitamin D supplementation along with calcium in patient with low vitamin $\mathrm{D}$ levels is associated with improvement in bone mineral health and reduced risk for occurrence of fractures. ${ }^{61}$ However, it is not yet known whether supplementation of vitamin $\mathrm{D}$ would prevent the occurrence of non-skeletal diseases associated with its deficiency. Some studies have shown that vitamin $\mathrm{D}$ supplementation improves vascular functions and reduces oxidative stress in vitamin D deficient patients. ${ }^{62-64}$ A randomized controlled trial has demonstrated the beneficial effects of calcium and vitamin $\mathrm{D}$ supplementation in reducing cancer risk in postmenopausal women. ${ }^{65}$ There are also conflicting results with the use of vitamin D supplementation in prevention of cardiovascular diseases or cancer. ${ }^{66-67}$ Thus, further studies are warranted to establish whether 
vitamin D supplementation is beneficial in providing non-skeletal benefits in patients with vitamin $\mathrm{D}$ deficiency.

\section{CONCLUSION}

Vitamin $\mathrm{D}$ is a fat soluble prohormone synthesized in our body with the help of UV-B radiation. It undergoes a process of two-step metabolic activation in the body, first 25-hydroxylation in the liver and followed by 1-alfa hydroxylation in the kidneys to form the biologically active metabolite 1,25 dihydroxycholecalciferol or calcitriol. Calcitriol binds to the vitamin D receptors and mediates its actions. Its major role is to maintain the bone mineral homeostasis and regulate the serum calcium levels. However, the presence of vitamin D receptors at sites other than those involved in bone mineral homeostasis and occurrence of extra renal 1-alfa hydroxylase enzyme led to the identification of the pleiotropic effects of vitamin D as an anti-inflammatory, anti-apoptotic, anti-fibrotic and immunomodulatory agent. The serum 25 hydroxyvitamin D levels are used as biomarkers to assess the vitamin D stores of an individual. Based on the serum 25 hydroxyvitamin D levels, individuals can be classified into vitamin D deficient, insufficient and those with normal vitamin D levels. Vitamin D toxicity refers to serum 25 -hydroxyvitamin D levels $>150 \mathrm{ng} / \mathrm{ml}$ and is predominantly due to excessive vitamin $\mathrm{D}$ supplementation. Vitamin D deficiency is highly prevalent and is associated with various diseases like osteoporosis, bone fractures, myocardial infarction and cancer. The studies regarding vitamin $\mathrm{D}$ supplementation in providing non-skeletal benefits is ambiguous and conflicting. Thus, further research is required in this field to uncover the potential benefits of the sunshine hormone in various non-skeletal diseases like cardiovascular diseases and cancer.

\section{ACKNOWLEDGEMENT}

I would like to thank Dr. Steven. A. Dkhar, Late Professor and Head, Department of Clinical Pharmacology, JIPMER, Puducherry, India, for his valuable support in writing this review.

\section{CONFLICT OF INTEREST}

The authors declare no conflict of interest.

\section{ABBREVIATIONS}

UVB: Ultraviolet B; MED: Minimal erythemal dose; IU: International units; DBPs: Vitamin D binding proteins; CYP27B1: Cytochrome P27B1; VDR: Vitamin D receptors; RXR: Retinoid X receptor; VDRE: Vitamin D response elements; RDA: Recommended dietary allowances; IOM: Institute of Medicine; ICMR: Indian Council of Medical Research; HPLC: High performance liquid chromatography; RIA: Radioimmunoassay; ELISA: Enzyme-linked immunosorbent assay; LCMS/MS: Liquid chromatography-tandem mass spectrometry; EDTA: Ethylenediamine-tetraacetic acid.

\section{REFERENCES}

1. DeLuca HF. History of the discovery of vitamin D and its active metabolites. BoneKEy Rep. 2014;3:479. doi:10.1038/bonekey.2013.213.

2. Chesney RW. Theobald Palm and his remarkable observation: How the sunshine vitamin came to be recognized. Nutrients. 2012;4(1):42-51.

3. Mellanby E. An experimental investigation of rickets. Nutr Rev. 1976;34(11):338-40.

4. McCollum EV, Simmonds N, Becker JE, Shipley PG. An experimental demonstration of the existence of a vitamin which promotes calcium deposition. J Biol Chem. 1922;53(2):293-312.

5. Wolf $\mathrm{G}$. The discovery of vitamin D: the contribution of Adolf Windaus. J Nutr. 2004;134(6):1299-302.

6. Norman AW. From vitamin D to hormone D: fundamentals of the vitamin D endocrine system essential for good health. Am J ClinNutr. 2008;88(2):491S-9S.

7. Holick MF. The cutaneous photosynthesis of previtamin D3: a unique photoendocrine system. J Invest Dermatol. 1981;77(1):51-8.
8. Chen TC, Chimeh F, Lu Z, Mathieu J, Person KS, Zhang A, et al. Factors that influence the cutaneous synthesis and dietary sources of vitamin D. Arch Biochem Biophys. 2007;460(2):213-7.

9. Wacker M, Holick MF. Sunlight and Vitamin D: A global perspective for health Dermatoendocrinol. 2013;5(1):51-108.

10. Christakos S, Ajibade DV, Dhawan P, Fechner AJ, Mady LJ. Vitamin D: Metabolism. Endocrinol Metab Clin North Am. 2010;39:243-53.

11. Tsiaras W, Weinstock M. Factors influencing vitamin D status. Acta Derm Venereol 2011;91(2):115-24.

12. Schmid A, Walther B. Natural vitamin D content in animal products. Adv Nutr Int Rev J. 2013;4(4):453-62.

13. Raubenheimer EJ, Noffke CEE. Vitamin D and health: a historical overview. SA Orthop J. 2011;10(2):39-43.

14. O'Mahony L, Stepien M, Gibney MJ, Nugent AP, Brennan L. The potential role of vitamin $D$ enhanced foods in improving vitamin $D$ status. Nutrients. 2011;3(12):1023-41.

15. Mostafa WZ, Hegazy RA. Vitamin D and the skin: Focus on a complex relationship: A review. J Adv Res. 2015;6(6):793-804.

16. Lehmann U, Hirche F, Stangl GI, Hinz K, Westphal S, Dierkes J. Bioavailability of vitamin D2 and D3 in healthy volunteers, a randomized placebo-controlled trial. J Clin Endocrinol Metab. 2013;98(11):4339-45.

17. Mulligan GB, Licata A. Taking vitamin D with the largest meal improves absorption and results in higher serum levels of 25-hydroxyvitamin D. J Bone Miner Res. 2010;25(4):928-30.

18. Zerwekh JE. Blood biomarkers of vitamin D status. Am J ClinNutr. 2008;87(4):1087S-91S.

19. Bikle DD. Vitamin D Metabolism, Mechanism of Action, and Clinical Applications Chem Biol. 2014;21(3):319-29.

20. Pereira F, Larriba MJ, Munoz A. Vitamin D and colon cancer. Endocr Relat Cancer. 2012;19(3):R51-71.

21. Christakos S, Dhawan P, PortaA, Mady LJ, Seth T. Vitamin D and intestinal calcium absorption. Mol Cell Endocrinol. 2011;347(1-2):25-9.

22. Jones G, Strugnell SA, DeLuca HF. Current understanding of the molecular actions of vitamin D. Physiol Rev. 1998;78(4):1193-231.

23. Fukumoto S. Phosphate metabolism and vitamin D. BoneKEy Rep. 2014 doi:10.1038/bonekey.2013.231.

24. DeLuca HF. Overview of general physiologic features and functions of vitamin D. Am J ClinNutr. 2004;80(6):1689S-96S

25. Lai YH, Fang TC. The Pleiotropic Effect of Vitamin D. ISRN Nephrol. 2013. http:// dx.doi.org/10.5402/2013/898125.

26. Agrawal D, Yin K. Vitamin D and inflammatory diseases. J Inflamm Res. 2014;7:69-87.

27. Adams JS, Sharma OP, Gacad MA, Singer FR. Metabolism of 25-hydroxy vitamin D3 by cultured pulmonary alveolar macrophages in sarcoidosis. J Clin Invest. 1983;72(5):1856-60.

28. Zehnder D, Bland R, Williams MC, McNinch RW, Howie AJ, Stewart PM, et al. Extrarenal expression of 25-hydroxyvitamin D3-1-alpha-hydroxylase. J Clin Endocrinol Metab. 2001;86(2):888-94.

29. Hewison M, Zehnder D, Bland R, Stewart PM. 1-alpha-hydroxylase and the action of vitamin D. J MolEndocrinol. 2000;25:141-8

30. Institute of Medicine | Dietary Reference Intakes for Calcium and Vitamin D [internet]. IOM. [cited 2018 Jun 7]. Available from: https://www.nationalacademies.org/hmd/ /media/Files/Report\%20Files/2010/Dietary-Reference-Intakesfor-Calcium-and-Vitamin-D/Vitamin \% 20D \% 20and \% 20Calcium \% 202010\% 20 Report\%20Brief.pdf.

31. Holick MF, Binkley NC, Bischoff FHA, Gordon CM, Hanley DA, Heaney RP, et al. Evaluation, treatment, and prevention of vitamin $\mathrm{D}$ deficiency: an Endocrine Society Clinical Practice guideline. J Clin Endocrinol Metab. 2011;96(7):1911-30.

32. Indian Council of Medical Research | Nutrient requirements and recommended dietary allowances for Indians [internet]. ICMR. [cited 2018 Jun 7]. Available from: http://icmr.nic.in/final/rda-2010.pdf.

33. Lips P. Relative Value of 25(OH)D and 1,25(OH)2D Measurements. J Bone Miner Res. 2007;22(11):1668-71

34. Zerwekh JE. The measurement of vitamin D: analytical aspects. Ann Clin Biochem. 2004;41(4):272-81.

35. Romagnoli E, Pepe J, Piemonte S, Cipriani C, Minisola S. Management of endocrine disease: Value and limitations of assessing vitamin $D$ nutritional status and advised levels of vitamin D supplementation. Eur J Endocrinol. 2013;169:R59-R69.

36. Roth HJ, Schmidt GH, Weber H, Niederau C. Accuracy and clinical implications of seven 25-hydroxyvitamin D methods compared with liquid chromatographytandem mass spectrometry as a reference. Ann Clin Biochem. 2008;45(2): $153-9$

37. Binkley N, Krueger D, Cowgill CS, Plum L, Lake E, Hansen KE, et al. Assay variation confounds the diagnosis of hypovitaminosis D: A call for standardization. J Clin Endocrinol Metab. 2004;89(7):3152-7.

38. Seamans KM, Cashman KD. Existing and potentially novel functional markers of 
vitamin D status: a systematic review. Am J ClinNutr. 2009;89(6):1997S-2008S.

39. Colak A, Toprak B, Dogan N, Ustuner F. Effect of sample type, centrifugation and storage conditions on vitamin D concentration. Biochem Medica. 2013; 23(3):321-5.

40. Antoniucci DM, Black DM, Sellmeyer DE. Serum 25-hydroxyvitamin D is unaffected by multiple freeze-thaw cycles. Clin Chem. 2005;51(1):258-61.

41. Yu CL, Falk RT, Kimlin MG, Rajaraman P, Sigurdson AJ, Horst RL, et al. The impact of delayed blood centrifuging, choice of collection tube, and type of assay on 25-hydroxyvitamin D concentrations. Cancer Causes Control. 2010;21(4):643-8.

42. Abrams SA, Griffin IJ, Hawthorne KM, Gunn SK, Gundberg CM, Carpenter TO. Relationships among vitamin D levels, parathyroid hormone, and calcium absorption in young adolescents. J Clin Endocrinol Metab. 2005;90(10):5576-81.

43. Hollis BW. Circulating 25-hydroxyvitamin D levels indicative of vitamin D sufficiency: implications for establishing a new effective dietary intake recommendation for vitamin D. J Nutr. 2005;135(2):317-22.

44. Heaney RP. Functional indices of vitamin D status and ramifications of vitamin $D$ deficiency.Am J ClinNutr. 2004;80(6):1706S-9S.

45. Spiro A, Buttriss JL. Vitamin D: An overview of vitamin D status and intake in Europe: Vitamin D status and intake in Europe. Nutr Bull. 2014;39(4):322-50.

46. Lips P. Vitamin D deficiency and secondary hyperparathyroidism in the elderly: consequences for bone loss and fractures and therapeutic implications. Endocr Rev. 2001;22(4):477-501.

47. Özkan B, Hatun S, Bereket A. Vitamin D intoxication. Turk J Pediatr. 2012;54(2):93-8.

48. Palacios C, Gonzalez L. Is vitamin D deficiency a major global public health problem?. J Steroid Biochem Mol Biol. 2014;144:138-45.

49. Selvarajan S, Gunaseelan V, Anandabaskar N, Xavier AS, Srinivasamurthy S, Kamalanathan SK, et al. Systematic review on vitamin D level in apparently healthy Indian population and analysis of its associated factors. Indian J Endocr Metab 2017;21(5):765-75.

50. Shivane VK, Sarathi V, Bandgar T, Menon P, Shah NS. High prevalence of hypovitaminosis $D$ in young healthy adults from the western part of India. Postgrad Med J. 2011;87(1030):514-8

51. Joshi D, Center JR, Eisman JA. Vitamin D deficiency in adults. Aust Prescr. 2010;33(4):103-6.

52. Holick MF. Resurrection of vitamin D deficiency and rickets. J Clin Invest. 2006;116(8):2062-72.

53. Holick MF. Vitamin D: A D-lightful solution for health. J Investig Med. 2011;59(6):872-80

54. Holvik K, Ahmed LA, Forsmo S, Gjesdal CG, Grimnes G, Samuelsen SO, et al. Low Serum levels of 25-Hydroxyvitamin D predict hip fracture in the elderly: A NOREPOS study. J Clin Endocrinol Metab. 2013;98(8):3341-50.

55. Boer IHD, Levin G, Robinson CC, Biggs ML, Hoofnagle AN, Siscovick DS, et al. Serum 25-hydroxyvitamin D concentration and risk for major clinical disease events in a community-based population of older adults: a cohort study. Ann Intern Med. 2012;156(9):627-34

56. Mheid IA, Patel R, Murrow J, Morris A, Rahman A, Fike L, et al. Vitamin D status is associated with arterial stiffness and vascular dysfunction in healthy humans. J Am Coll Cardiol. 2011;58(2):186-92.

57. Chien KL, Hsu HC, Chen PC, Lin HJ, Su TC, Chen MF, et al. Total 25-hydroxy vitamin D Concentration as a predictor for all-cause death and cardiovascular event risk among Ethnic Chinese adults: A cohort study in a Taiwan community. PLoS One. 2015;10(3):e0123097.

58. Schöttker B, Jorde R, Peasey A, Thorand B, Jansen EHJM, Groot LD, et al. Vitamin $D$ and mortality: meta-analysis of individual participant data from a large consortium of cohort studies from Europe and the United States. BMJ 2014;348:g3656.

59. Gaksch M, Jorde R, Grimnes G, Joakimsen $\mathrm{R}$, Schirmer $\mathrm{H}$, Wilsgaard $T$, et al. Vitamin D and mortality: Individual participant data meta-analysis of standardized 25- hydroxyvitamin D in 26916 individuals from a European consortium. PLoS One. 2017;12(2):e0170791.

60. Jacobs ET, Kohler LN, Kunihiro AG, Jurutka PW. Vitamin D and colorectal, breast, and prostate cancers: A review of the epidemiological evidence. J Cancer. 2016;7(3):232-40

61. Lips P, Gielen E, Schoor NMV. Vitamin D supplements with or without calcium to prevent fractures. BoneKEy Reports. 2014;512.

62. Anandabaskar N, Selvarajan S, Dkhar SA, Kamalanathan SK, Tamilarasu K Bobby Z. Effect of Vitamin D supplementation on vascular functions and oxidative stress in type 2 diabetic patients with Vitamin D deficiency. Indian J Endocr Metab. 2017;21(4):555-63.

63. Sunbul M, Çinçin A, Bozbay M, Mammadov C, Atas H, Özsenel EB, et al. Arterial stiffness parameters associated with vitamin D deficiency and supplementation in patients with normal cardiac functions. Turk Kardiyol Dern Ars 2016;44(4):281-8.

64. Foroozanfard F, Jamilian M, Bahmani F, Talaee R, Talaee N, Hashemi T, et al. Calcium plus vitamin $D$ supplementation influences biomarkers of inflammation and oxidative stress in overweight and vitamin D-deficient women with polycystic ovary syndrome: a randomized double-blind placebo-controlled clinical trial. ClinEndocrinol. 2015;83(6):888-94.

65. Lappe JM, Travers GD, Davies KM, Recker RR, Heaney RP. Vitamin D and calcium supplementation reduces cancer risk: results of a randomized trial. Am J Clin Nutr 2007;85(6):1586 -91.

66. Gepner AD, Ramamurthy R, Krueger DC, Korcarz CE, Binkley N, Stein JH. A prospective randomized controlled trial of the effects of vitamin $D$ supplementation on cardiovascular disease risk. PLoS One. 2012;7(5):e36617.

67. Sperati F, Vici P, Maugeri SM, Stranges S, Santesso N, Mariani L, et al. Vitamin D Supplementation and Breast Cancer Prevention: A Systematic Review and Meta-Analysis of Randomized Clinical Trials. PLoS One. 2013;8(7):e69269.

Article History: Submission Date : 04-07-2018 ; Revised Date : 11-07-2017; Acceptance Date : 06-09-2018.

Cite this article: Anandabaskar N, Selvarajan S, Kamalanathan S. Vitamin D in Health and Disease - An Update. J Young Pharm. 2018;10(4):381-7. 